\title{
Review
}

\section{Non-conventional affinity chromatography of serine proteinases and their inhibitors ${ }^{\star}$}

\author{
Antoni Polanowski ${ }^{\bowtie}$, Anna Wilimowska-Pelc, Jolanta Kowalska, Joanna Grybel, \\ Monika Żelazko and Tadeusz Wilusz
}

\section{Institute of Biochemistry and Molecular Biology, University of Wroctaw, Wroctaw, Poland}

Received: 30 May, 2003; revised: 23 August, 2003; accepted: 04 September, 2003

Key words: affinity chromatography, proteolytic enzymes, trypsin, chymotrypsin, serine proteinase inhibitors, $\alpha_{1}$-proteinase inhibitor, Kazal-type inhibitors, high $\mathrm{NaCl}$ concetration

\begin{abstract}
From among a wide variety of protein purification techniques affinity chromatography has proved to be particularly effective for separation of proteolytic enzymes and their inhibitors. In this article, following a general description of affinity adsorbents used for purification of proteinases, we overview a simple separation procedure for some serine proteinases and their inhibitors by way of affinity chromatography in the presence of high $\mathrm{NaCl}$ concentration. It has been shown that some highly specific trypsin inhibitors exhibit also antichymotrypsin activity when high concentration of $\mathrm{Na}^{+}$but not $\mathrm{K}^{+}$or $\mathrm{Li}^{+}$ions are present in the reaction mixture. Taking advantage of this phenomenon the virgin forms of trypsin inhibitors from squash seeds, Kazal-type inhibitor from porcine pancreas and $\alpha_{1}$-proteinase inhibitor from human and sheep plasma, as an example, were separated using immobilized chymotrypsin or its inactive derivative methylchymotrypsin in the presence of $5 \mathrm{M} \mathrm{NaCl}$.
\end{abstract}

Proteolytic enzymes play a regulatory role in the majority of fundamental processes ranging from protein synthesis to its degradation. Serine proteinases, for example, are recog- nized as important factors in the control of multiple pathways associated with coagulation, fibrinolysis, connective tissue turnover, homeostasis, fertilization, complement activa-

\footnotetext{
${ }^{\star}$ Presented at the XXX Winter School of Faculty of Biotechnology, Jagiellonian University, Kościelisko, Poland, 28th February-4th March, 2003.

${ }^{凶}$ Address for correspondence: Antoni Polanowski, Institute of Biochemistry and Molecular Biology, University of Wrocław, ul. Tamka 2, 50-137 Wrocław, Poland; tel.: (48 71) 375 2394; fax: (48 71) 375 2608; e-mail: apolan@bf.uni.wroc.pl
}

Abbreviations: BPTI, basic pancreatic trypsin inhibitor; CMTI, Cucurbita maxima trypsin inhibitor; CyPTI, Cyclanthera pedata trypsin inhibitor; HNE, human neutrophil elastase; STI, soybean trypsin inhibitor. 
tion and inflammatory reaction. These enzymes are also involved in many diseases therefore, they are often targets for therapeutic intervention. Among substances that are able to selectively abrogate their action, serine proteinase inhibitors are of particular interest because they can be used either as drugs by themselves or may serve as a template for the design and development of highly specific drugs (Leung et al., 2000). No wonder, then, that much work has been done to develop effective and simple methods for purification of both proteolytic enzymes and their inhibitors.

\section{THE USE OF AFFINITY CHROMATOGRAPHY FOR PROTEINASE PURIFICATION}

Affinity chromatography can certainly be considered as one of the most effective ways for protein separation and purification. In many cases this technique is fast, quite simple and very efficient. The method relies upon specific and reversible binding of a protein to a ligand, usually immobilized on an insoluble, porous and inert support. The method, due to its selectivity, has been commonly used in separation of proteins and peptides both naturally occurring, and obtained by chemical or genetic engineering. In particular, affinity chromatography has been found to be convenient for separation of proteolytic enzymes and their inhibitors.

In the case of protease purification, immobilized substrates or their analogues as well as different types of synthetic or naturally occurring inhibitors have been used. Theoretically, the best ligand for affinity separation of enzymes seems to be the substrate itself, in practice however, its use is generally precluded by the rapid turnover of the enzymatic reaction resulting in immediate conversion of the substrate into product after contact with the target enzyme. Nevertheless, covalently coupled bovine hemoglobin was employed as a suit- able ligand for purification of alkaline protease from the larvae of Spilosoma obliqua (Anvar \& Saleemuddin, 2002), and aspartic proteinases (cathepsin D) from bovine spleen (Turk et al., 1977). It is worth noting that in the course of chromatography the hemoglobin undergoes enzymatic hydrolysis, so that in each consecutive run an enzyme molecules bind to immobilized products of hemoglobin degradation rather than to hemoglobin itself.

In a similar approach, trypsin, plasmin and chymotrypsin were purified on immobilized product-type ligands, e.g. a peptide with C-terminal L-arginine (Makriyannis \& Clonis, 1997), derivatives of L-arginine (Ishi \& Kasai, 1980) and L-lysine (Robinson et al., 1971) and methylester of D-tryptophan (Cuatrecasas et al., 1968).

Synthetic inhibitors of proteinases turned out to be very efficient ligands for many proteolytic enzymes. Immobilized $\varepsilon$-aminocaproyl-p-chlorobenzylamide $\cdot \mathrm{HCl}$ was used to purify thrombin (Thompson \& Davie, 1971) whereas benzamidine was employed for separation of human neutrophil elastase (Liau et al., 1993) as well as trypsin, pronase E and trypsin-like protease from urine (Kanamori et al., 1986). Besides, immobilized argininal semicarbazone-containing peptides, reversible inhibitors of trypsin and kallikrein, were found to be efficient ligands for serine proteinase purification (Basak et al., 1990). The peptide Val-D-Leu-Pro-Phe-Phe-Val-D-Leu, an inhibitor of aspartic proteinases (Kučerová et al., 1986), served for separation of gastricsin and pepsin from gastric juice.

Naturally occurring inhibitors are the best ligands for affinity purification of proteolytic enzymes. Some of them, however, are characterize by very low specificity which makes them "universal" affinity ligands allowing the isolation of proteases belonging to different families. An example of such an inhibitor is bacitracin, a branched cyclic dodecapeptide produced by Bacillus licheniformis, which was used for purification of metalloproteinases (Eijsink et al., 1991), cysteine proteinases 
(Irvine et al., 1993) and serine proteinases (Rudenskaya et al., 1995).

Another type of ligands includes group specific inhibitors, which are very selective and able to react exclusively with proteinases of a single class. An example of such an inhibitor is egg white cystatin, quite often used as an affinity ligand in the purification of cysteine proteinases from papain family (Tombaccini et al., 2001). Pepstatin A is known to provide an efficient means for the purification of aspartic proteinases of animal as well as plant origin. This inhibitor facilitated, for example, purification of calf chymosin (Kobayashi \& Murakami, 1978), aspartic proteinase from cucumber seeds (Wilimowska-Pelc et al., 1983a) and from Chlamydomonas reinhardtii (Wilusz \& Polanowski, 1985).

A number of specific inhibitors have been used for purification of serine proteinases. However, most of the naturally occurring protein inhibitors form inactive complexes with enzymes of different specificity. That creates a significant inconvenience, especially when an individual enzyme is to be separated from a mixture of several proteases, for example from pancreas or leukocyte extracts.

Bovine basic pancreatic trypsin inhibitor (BPTI) and inhibitors from legume seeds (Kunitz-type and Bowman-Birk-type) are the most often employed protein ligands in serine proteinase purification. BPTI inhibits several enzymes, among others trypsin, chymotrypsin and kallikrein, whereas the inhibitors from legume seeds, additionally, some pancreatic elastases. Taking advantage of even the small differences in their inhibition spectrum it is possible to separate, for example from pancreatic extract, first a mixture of trypsin and chymotrypsin on immobilized BPTI and then elastase with immobilized soybean inhibitor.

The best results in purification may be gained by using highly specific inhibitors. As yet, only a limited number of inhibitors have been shown to posses such a property. Chicken ovomucoid, a selective inhibitor of trypsin, was used as early as in 1970 (Feinstein, 1970) for purification of this enzyme. In our laboratory several very specific trypsin inhibitors were purified from seeds of Cucurbitaceae family. These inhibitors, e.g. CMTI (Cucurbita maxima trypsin inhibitor), under standard conditions inhibit only trypsin and have neither antichymotrypsin nor antielastase activity, therefore they are very good ligands for selective purification of trypsin. A method utilizing sequential affinity chromatography on CMTI-, BPTI- and STI (soybean trypsin inhibitor)-Sepharose columns allowed, due to the different specificities of the inhibitors, simultaneous separation of trypsin, chymotrypsin and elastase from chicken (Guyonnet et al., 1999) and goose (Żelazko, 2000) pancreas.

The usefulness of an inhibitor in the purification procedure depends entirely on the association-dissociation rates of the ligand-protein complex, thus, carefully chosen conditions for adsorption and elution may allow for a selective recovery of the enzymes. Applying, for example, a $\mathrm{pH}$ gradient in the range 4.5-2.75 for elution of bovine trypsin from immobilized chicken ovomucoid, led to separation of the $\alpha$ and $\beta$-forms (Robinson et al., 1971). Similarly, selective elution of human leukocyte proteinases from immobilized BPTI affinity column enabled separation of cathepsin $\mathrm{G}$ from human neutrophile elastase (HNE) (Baugh \& Travis, 1976).

Also, application of different ionic strengths gives a similar effect. Chromatography of bovine chymotrypsin on immobilized BowmanBirk inhibitor resulted in separation of A $\alpha$-chymotrypsin from the B-form, when 0.01 $\mathrm{M} \mathrm{HCl}$ with and without $0.5 \mathrm{M} \mathrm{NaCl}$, respectively, was used for elution (Wilimowska-Pelc et al., 1983b). 


\section{THE USE OF AFFINITY CHROMATOGRAPHY FOR PURIFICATION OF PROTEINASE INHIBITORS}

The usefulness of immobilized trypsin, $\alpha$-chymotrypsin and kallikrein for purification of proteinase inhibitors was shown as early as in 1967 by Fritz et al. To date, thousands of papers have been published on this subject. In this paper discussion is limited to some selected problems which arose at different stages of our research on serine proteinase inhibitors. Due to its availability and simplicity trypsin immobilized on Sepharose has been a common tool in preparation of many protein inhibitors. The method was utilized, for example, for purification of BPTI from bovine lungs (Kassel \& Marciniszyn, 1971) and inhibitors from squash seeds (Polanowski et al., 1980). The mixture of proteins subjected to affinity purification is applied onto the column under slightly basic conditions and elution of an inhibitor is accomplished at a pH below 3.0. In contrast to BPTI, which is recovered as a single, one chain molecule, the preparation of inhibitors from squash seeds consists not only of several isoinhibitors, but also of a mixture of their virgin and modified forms (peptide bond $\mathrm{P}_{1}-\mathrm{P}^{\prime}{ }_{1}$ hydrolyzed). This is so because some serine proteinase inhibitors can be specifically cleaved at the scissile bond by their target enzymes under acidic conditions. The hydrolysis of the reactive site peptide bond during dissociation of an enzyme-inhibitor complex considerably makes the purification more difficult particularly when several isoinhibitors, similar in terms of size and electric charge, are present in a solution. For instance a mixture of three squash trypsin inhibitors (CMTI I, CMTI III and CMTI IV), of which two consist of 29 and one of 31 amino-acid residues, upon chromatography on immobilized trypsin yields six inhibitory forms, three virgin and three modified. Due to their similarity in terms of activity, molecular size and electric charge their final separation appeared to be extremely difficult.

Immobilized trypsin under acidic conditions is prone to split not only the reactive site peptide bond of the inhibitor being separated, but also hydrolyzes other bonds causing, e.g. inactivation of Kazal-type temporary inhibitors (Laskowski et al., 1971). In this case applying the immobilized protease for purification of temporary inhibitors is practically useless. To avoid this inconvenience the catalytically inactive anhydrotrypsin (Ako et al., 1972) have been used as ligands in affinity chromatography for isolation of virgin forms of inhibitors. The chemically modified enzyme, having of active site Ser195 altered to dehydroalanine, retain its ability to form stoichiometric complexes with inhibitors. Such modified enzyme was used for purification of virgin forms of secretory trypsin inhibitors from pancreas of turkey (Bogard \& Laskowski, 1979), and of goose and duck (Wilimowska-Pelc et al., 1996; 1999a), as well as from seeds of various species of Cucurbitaceae (Polanowski et al., 1987). It should be pointed out however, that chemical modification of enzymes is a tedious multistage process involving convertion of an enzym to its PMSF (phenylmethylsulfonyl fluoride)-derivative followed by dihydration and finally inactivation of unmodified molecules with TLCK ( $N \alpha$-p-tosyl-L-lysine chloromethyl ketone).

\section{PURIFICATION OF PROTEINASES AND THEIR INHIBITORS IN THE PRESENCE OF HIGH SALT CONCENTRATION}

The aforementioned results indicate that ionic strength significantly affects the interaction between some enzymes and inhibitors. Table 1 shows the influence of $\mathrm{NaCl}$ concentration on equilibrium association constants of selected inhibitors with some serine proteinases. The data indicate that only $\alpha$-chy- 
motrypsin and the chymotrypsin-like protease subtilisin Carlsberg are sensitive to high salt concentration. The activity of the remaining enzymes was almost unchanged. An increase of $K_{\mathrm{a}}$ for the interaction of an inhibitor with chymotrypsin and $k_{\text {cat }} / K_{\mathrm{m}}$ for substrate hydrolysis occurs only in the presence of $\mathrm{Na}^{+}$ ions, while $\mathrm{K}^{+}$and $\mathrm{Li}^{+}$do not affect the activity of chymotrypsin (Wesołowska et al., 2001).

The favorable effect of high ionic strength on the equilibrium association constant was taken
HNE with azurocidin on the second column. The selective conditions employed subsequently for recovery of the enzymes yielded cathepsin G, HNE and azurocidin separated from each other (Watorek et al., 1996).

The effect of high $\mathrm{NaCl}$ concentration on the association constant of some trypsin inhibitors with chymotrypsin has also been employed for separation of trypsin and chymotrypsin from extracts of porcine pancreas. A specific trypsin inhibitor from the seeds of squash (CMTI I) was

Table 1. The effect of high $\mathrm{NaCl}$ concentration on the association constants $\left(K_{\mathrm{a}}\left[\mathrm{M}^{-1}\right]\right)$ for the interaction of selected trypsin inhibitors with some serine proteinases.

The association constants were determined in $0.1 \mathrm{M}$ Tris/ $\mathrm{HCl}, 0.02 \mathrm{M} \mathrm{CaCl}_{2}, 0.005 \%$ Triton X-100, pH 8.3 with appropriate $\mathrm{NaCl}$ concentration at $22^{\circ} \mathrm{C}$.

\begin{tabular}{|c|c|c|c|c|c|c|}
\hline \multirow{2}{*}{ ENZYME } & \multirow{2}{*}{$\begin{array}{l}\mathrm{NaCl} \text { conc. } \\
{[\mathrm{M}]}\end{array}$} & \multicolumn{5}{|c|}{ INHIBITOR } \\
\hline & & LUTI $^{\text {a) }}$ & $\mathrm{BPTI}^{\mathrm{b}), \mathrm{c}}$ & CMTII d) & CyPTI V $^{\text {e) }}$ & CyPTI VII $^{\text {e) }}$ \\
\hline \multirow{2}{*}{$\begin{array}{c}\text { Bovine } \\
\alpha \text {-chymotrypsin } \\
(\text { EC } 3.4 .21 .1)\end{array}$} & 0 & $5.0 \times 10^{5}$ & $2.0 \times 10^{7}$ & $4.0 \times 10^{4}$ & $6.4 \times 10^{4}$ & $1.7 \times 10^{6}$ \\
\hline & 3 & $6.6 \times 10^{7}$ & $5.8 \times 10^{9}$ & $2.8 \times 10^{7}$ & $3.0 \times 10^{7}$ & $1.3 \times 10^{9}$ \\
\hline \multirow{2}{*}{$\begin{array}{l}\text { Subtilisin Carlsberg } \\
\text { (EC } 3.4 .21 .62)\end{array}$} & 0 & $4.5 \times 10^{6}$ & $3.4 \times 10^{2}$ & nd & nd & nd \\
\hline & 3 & $1.3 \times 10^{9}$ & $1.1 \times 10^{3}$ & nd & nd & nd \\
\hline Human leukocyte & 0.5 & $9.1 \times 10^{4}$ & $1.1 \times 10^{6}$ & nd & nd & nd \\
\hline (EC 3.4.21.37) & 3 & $2.9 \times 10^{5}$ & $2.0 \times 10^{7}$ & nd & nd & nd \\
\hline $\begin{array}{c}\text { Porcine pancreatic } \\
\text { elastase }\end{array}$ & 0 & $8.6 \times 10^{3}$ & $4.6 \times 10^{3}$ & nd & nd & nd \\
\hline (EC 3.4.21.36) & 3 & $2.9 \times 10^{4}$ & $1.6 \times 10^{4}$ & nd & nd & nd \\
\hline
\end{tabular}

a) Lorenc-Kubis et al., 2001; b) Wesołowska et al., 2001; c) Gonciarz, 1996; d) Jakimowicz, 1996; e) Kowalska, 2002. LUTI, Linum usitatissimum trypsin inhibitor; BPTI, basic pancreatic trypsin inhibitor; CMTI, Cucurbita maxima trypsin inhibitor; CyPTI, Cyclantera pedata trypsin inhibitor.

advantage of in developing a non-conventional method of purification of some serine proteinases and their inhibitors in the presence of high salt concentration. The method was used among others, for separation of cathepsin G from other neutrophil proteinases. Advantageous was the fact that cathepsin $G$ in the presence of at least $1 \mathrm{M} \mathrm{NaCl}$ forms a complex with the specific trypsin inhibitor CMTI I. Loading of the neutrophil granules homogenate under slightly basic conditions in the presence of $1 \mathrm{M} \mathrm{NaCl}$ on a tandem of CMTI Iand BPTI-Sepharose columns resulted in adsorption of cathepsin $\mathrm{G}$ on the first, and of used as a ligand. First, applying of the pancreatic extract on a column with immobilized CMTI under slightly basic conditions, resulted in adsorption of trypsin which was removed at $\mathrm{pH}$ 3.0. Then the trypsin free effluent, upon adjusting it with $\mathrm{NaCl}$ to $5 \mathrm{M}$ concentration was loaded to the same column equilibrated with $5 \mathrm{M} \mathrm{NaCl}$. The bound chymotrypsin could be recovered with water.

The data of our studies indicated that some inhibitors, although specific for trypsin are able to inhibit also chymotrypsin and the chymotrypsin-like enzymes in the presence of high salt concentration. This salt effect was 
applied for the purification of trypsin inhibitors from the seeds of Cucurbita ficifolia and C. pepo as well as Kazal-type inhibitor from porcine pancreas, by affinity chromatography on immobilized chymotrypsin in the presence of $5 \mathrm{M} \mathrm{NaCl}$ (Wilimowska-Pelc et al., 1999b). The inhibitors were adsorbed onto the column under slightly basic conditions in the presence of $5 \mathrm{M} \mathrm{NaCl}$ and after washing out of all immobilized chymotrypsin in the presence of $5 \mathrm{M} \mathrm{NaCl}$, could be eluted in two sets. The first set, comprising 5 of the 7 adsorbed trypsin inhibitors, was recovered with water, the remaining two inhibitors required acidic conditions for dissociation and were eluted with $0.01 \mathrm{M} \mathrm{HCl}$. Figure 1 shows the amino-acid sequences and equilibrium association constants with bovine $\beta$-trypsin and $\alpha$-chymo-

$\begin{array}{llll} & & \begin{array}{c}K_{\mathrm{a}}\left[\mathrm{M}^{-1}\right] \\ \beta \text {-trypsin }\end{array} & \begin{array}{c}K_{\mathrm{a}}\left[\mathrm{M}^{-1}\right] \\ \alpha \text {-chymotrypsin }\end{array} \\ \text { CYPTI V } & \text { RICPRILMECKADSDCLAQCICQESGFCG } & >10^{11} & 6.35 \times 10^{4} \\ \text { CYPTI VII } & \text { ARICPRILMKCKKDSDCLAECICQEHGFCG } & >10^{11} & 1.69 \times 10^{6}\end{array}$

Figure 1. Amino-acid sequences of representative trypsin inhibitors from Cyclanthera pedata and equilibrium association constants for their interaction with bovine $\beta$-trypsin and $\alpha$-chymotrypsin.

Inhibitors were purified by affinity chromatography on immobilized chymotrypsin and recovered under different conditions. CyPTI V represents the inhibitors eluting with water whereas CyPTI VII those eluting with $0.01 \mathrm{M} \mathrm{HCl}$. The amino-acid residues different in the two inhibitors are printed in bold.

ballast proteins, the inhibitors could be released either with water or a buffer of low ionic strength. In contrast to trypsin, the use of immobilized chymotrypsin in the presence of $5 \mathrm{M} \mathrm{NaCl}$ for purification of those inhibitors allowed to obtain them in their virgin forms (reactive site peptide bond intact). Moreover this technique enables purifying the intact Kazal-type inhibitor from porcine pancreas.

It is worth noting that under standard conditions complexes of serine proteinase-inhibitors dissociate at $\mathrm{pH}$ below 3.0 whereas, in the presence of $5 \mathrm{M} \mathrm{NaCl}$, inhibitors from C. ficifolia and C. pepo, even under acidic conditions ( $\mathrm{pH}<3.0$ ), do not dissociate from the ligand. This feature creates possibility of removing nonspecifically bound proteins by washing them out both under neutral and acid conditions in the presence of $5 \mathrm{M} \mathrm{NaCl}$ followed by eluting the target protein with a solution of low ionic strength.

In contradistinction to that the inhibitors from Cyclanthera pedata, belonging to the same squash inhibitor family, when bound to trypsin of two representative inhibitors of both sets. CyPTI V is an example of the inhibitors removable from the ligand with water and CyPTI VII represents those eluting with 0.01 M HCl (Kowalska, 2002). Both inhibitors form very strong complexes with bovine $\beta$-trypsin. The inhibitors eluting under acidic conditions are more basic proteins and their association constants with bovine $\alpha$-chymotrypsin exceed about 30-fold those of the inhibitors removable with water. This distinction may be the reason of their different affinity for chymotrypsin. The data indicate that the differences in the association constants of inhibitors with chymotrypsin can be turn to account in their separation. Employing the described method all trypsin inhibitors, comprising of 29 to 30 amino-acid residues, present in the extract were purified in virgin forms.

It should be emphasize that the described method is suitable for purification of only such inhibitors which are not susceptible to degradation by chymotrypsin in the presence of high salt. An attempt to purify, for example, 
trypsin inhibitor from flax seeds failed because the enzyme, under the condition used, totally degraded it (Kowalska, 2002). Taking that into account, we utilized for affinity chromatography, the catalytically inactive methylchymotrypsin. The technique takes advantage of the fact that chymotrypsin methylated at the position His57 to 3-methyl histidine loses its catalytic activity while retaining the capacity to form complexes with inhibitors (Ryan \& Feeney, 1975). In contrast to trypsin modification, the method of chemical modification of His57 in chymotrypsin is very simple and efficient. Under specified conditions, strong chymotrypsin inhibitors interact with the modified enzyme at low ionic strength, whereas weak inhibitors require the presence of high salt concentration for adsorption. Moreover, inhibitors specific for trypsin can also be separated on the same immobilized enzyme but only in the presence of $5 \mathrm{M} \mathrm{NaCl}$. The bound inhibitors can be selectively recovered from the column using either elution with decreasing salt concentration or a combination of salt concentration and $\mathrm{pH}$ gradient.

Employing this method we purified the above mentioned trypsin inhibitor from flax seeds LUTI (Linum usitatissimum trypsin inhibitor) (Lorenc-Kubis et al., 2001) and $\alpha_{1}$-antiproteinase from human and ovine plasma (Grybel \& Wilusz, 2003 ). For the purification of the latter immobilized active proteinases are useless since with $\alpha_{1}$-antiproteinase they form practically irreversible complexes. To overcome this problem, Drechsel et al. (1984) employed immobilized anhydrochymotrypsin for purification of $\alpha_{1}$-antiproteinase and for desorption they used another inhibitor of chymotrypsin, namely chymostatin. Economic considerations however, militate against the use of chymostatin in large-scale purification of $\alpha_{1}$-antiproteinase for therapeutic purposes due to the high cost of this substance. In our procedure, the albumin fraction of plasma is applied to immobilized methylchymotrypsin in the presence of $5 \mathrm{M} \mathrm{NaCl}$ and after washing out of balast protein with a buffer containing $5 \mathrm{M} \mathrm{NaCl}$ the inhibitor is eluted with water. It was proved that this simple technique can be usable for separation of $\alpha_{1}$-proteinase inhibitor from the serum of animals and from the milk of transgenic livestock.

Application of immobilized chymotrypsin and methylchymotrypsin in the presence of high salt concentration for affinity chromatography seems to be a very promising technique for purification of serine proteinase inhibitors in their virgin forms as well as those belonging to the serpin family.

\section{R E F E R E N C E S}

Ako H, Foster RJ, Ryan CA. (1972) The preparation of anhydro-trypsin and its reactivity with naturally occurring proteinase inhibitors. Biochem Biophys Res Commun.; 47: 1402-7.

Anvar A, Saleemuddin M. (2002) Purification and characterization of digestive alkaline protease from the larvae of Spilosoma obliqua. Archiv Insect Biochem Physiol.; 51: $1-12$.

Basak A, Gong YT, Cromlish JA, Paquin JA, Jean F, Seidah NG, Lazure C, Chretien M. (1990) Syntheses of argininal semicarbazone containing peptides and their application in the affinity chromatography of serine proteinases. Int J Peptide Protein Res.; 36: 7-17.

Baugh RJ, Travis J. (1976) Human leukocyte granule elastase: Rapid isolation and characterization. Biochemistry.; 15: 836-41.

Bogard WC. Jr, Laskowski M Jr. (1979) Turkey pancreatic secretory trypsin inhibitor. Federation of American Societies for Experimental Biology, 63rd. Annual Meeting, Abstracts of papers; 836, Abstract 3193.

Cuatrecasas P, Wilchek M, Anfinsen CB. (1968) Selective enzyme purification by affinity chromatography. Proc Natl Acad Sci U S A.; 61: 636-43.

Drechsel D, Karic L, Glaser CB. (1984) Affinity chromatography of $\alpha_{1}$-protease inhibitor us- 
ing Sepharose-4B-bound anhydrochymotrypsin. Anal Biochem.; 143: 141-5.

Eijsink VGH, van den Burg B, Venema G. (1991) High performance affinity chromatography of Bacillus neutral proteases. Biotechnol Appl Biochem.; 14: 275-83.

Feinstein G. (1970) Purification of trypsin by affinity chromatography on ovomucoid-Sepharose resin. FEBS Lett.; 7: 353-5.

Fritz H, Schult H, Hutzel M, Wiedemann M, Werle E. (1967) On protease inhibitors. IV. Isolation of protease inhibitors with the aid of water insoluble enzyme resins. Hoppe Seylers Z Physiol Chem.; 348: 308-12.

Gonciarz M. (1996) Site directed mutagenesis of CMTI I inhibitor from the seeds of Cucurbitaceae plants. The influence of $\mathrm{NaCl}$ on energy of interactions between serine proteinases and protein inhibitors. MSc Thesis, University of Wrocław, (in Polish).

Grybel J, Wilusz T. (2003) The use of immobilized methylchymotrypsin for the purification of human and sheep alpha-1-proteinase inhibitor $\left(\alpha_{1} \mathrm{PI}\right)$. Cell Mol Biol Lett.; 8: 263-74.

Guyonnet V, Tłuścik F, Long PL, Polanowski A, Travis J. (1999) Purification and partial characterization of the pancreatic proteolytic enzymes trypsin, chymotrypsin, and elastase from the chicken. $J$ Chromatogr.; 852A: 217-25.

Irvine JW, Coombs GH, North MJ. (1993) Purification of cysteine proteinases from trichomonads using bacitracin-Sepharose. FEMS Microbiol Lett.; 110: 113-9.

Ishi S, Kasai K. (1980) Affinity methods using arginine derivatives. Methods Enzymol.; 80: $842-8$.

Jakimowicz P. (1996) The effect of salt, methanol and saccharose on the interaction of selected proteinases with substrates and protein inhibitors. MSc thesis, University of Wrocław, (in Polish).

Kanamori A, Seno N, Matsumoto I. (1986) Preparation of high-capacity affinity adsorbents using formyl carriers and their use for lowand high-performance liquid affinity chroma- tography of trypsin-family proteases. $J$ Chromatogr.; 363: 231-42.

Kassell B, Marciniszyn MB. (1971) A simple method of purification of the basic trypsin inhibitor of bovine organs. In Proceedings of the International Research Conference on Proteinase Inhibitors. Fritz H, Tschesche $\mathrm{H}$. eds, pp 43-46. Walter de Gruyter, Berlin, New York.

Kobayashi H, Murakami K. (1978) Rapid and large scale isolation of chymosin (rennin) by pepstatin-aminohexylagarose. Agric Biol Chem.; 42: 2227-31.

Kowalska J. (2002) A new method of separation of serine proteinase inhibitors from the seeds of Cyctanthera pedata, Linum usitatissimum and Cannabis sativa. $\mathrm{PhD}$ Thesis, University of Wrocław, (in Polish).

Kučerová Z, Pohl J, Korbová L. (1986) Separation of human pepsin and gastricsin by affinity chromatography with an immobilized synthetic inhibitor. $J$ Chromatogr.; 376 : 409-12.

Laskowski M Sr, Schneider SL, Wilson KA, Kress LF, Mozejko JH, Martin SR, Kucich U, Andrews M. (1971) Naturally occurring trypsin inhibitors: further studies on purification and temporary inhibition. In Proceedings of the International Research Conference on Proteinase Inhibitors. Fritz H, Tschesche H. eds, pp 66-73. Walter de Gruyter, Berlin, New York.

Leung D, Abbenante G, Fairlie DP. (2000) Proteinase inhibitors: current status and future prospects. J Med. Chem.; 43: 305-41.

Liau DF, Yin NX, Ryan SF. (1993) Isolation of human polymorphonuclear leukocyte elastase by chromatography on immobilized benzamidine. Prep Biochem.; 23: 439-47.

Lorenc-Kubis I, Kowalska J, Pochroń B, Żużło A, Wilusz T. (2001) Isolation and amino acid sequence of a serine proteinase inhibitor from common flax (Linum usitatissimum) seeds. Chembiochem.; 2: 45-51.

Makriyannis T, Clonis YD. (1997) Design and study of peptide-ligand affinity chromatography adsorbents: application to the case of 
trypsin purification from bovine pancreas. Biotech Bioeng:; 53: 49-57.

Polanowski A, Wilusz T, Nienartowicz B, Cieślar E, Słomińska A, Nowak K. (1980) Isolation and partial amino acid sequence of the trypsin inhibitors from the seeds of Cucurbita maxima. Acta Biochim Polon.; 27: 371-82.

Polanowski A, Cieślar E, Otlewski J, Nienartowicz B, Wilimowska-Pelc A, Wilusz T. (1987) Protein inhibitors of trypsin from the seeds of Cucurbitaceae plants. Acta Biochim Polon.; 34: 395-406.

Robinson NC, Tye RW, Neurath H, Walsh KA. (1971) Isolation of trypsins by affinity chromatography. Biochemistry.; 10: 2743-7.

Rudenskaya GN, Bogdanova EA, Revina LP, Golovkin BN, Stepanov VM. (1995) Macluralisin - a serine proteinase from fruits of Maclura pomifera (Raf.) Schneid. Planta.; 196: 174-9.

Ryan DS, Feeney RE. (1975) The interaction of inhibitors of proteolytic enzymes with 3-methylhistidine-57-chymotrypsin. J Biol Chem.; 250: 843-7.

Thompson AR, Davie EW. (1971) Affinity chromatography of thrombin. Biochim Biophys Acta.; 250: 210-5.

Tombaccini D, Mocali A, Weber E, Paoletti F. (2001) A cystatin-based affinity procedure for the isolation and analysis of papain-like cysteine proteinases from tissue extracts. Anal Biochem.; 289: 231-8.

Turk V, Uhr I, Kregar J, Babnik F, Gubensek F, Smith R. (1977) Purification and some properties of native and immobilized cathepsin D. In Intracellular Protein Catabolism II. Turk V, Marks N. eds, pp 240-9. Plenum Press, New York, London.

Watorek W, Polanowski A, Wilusz T. (1996) The use of sequential affinity chromatography for separation of human neutrophil elastase, cathepsin G and azurocidin. Acta Biochim Polon.; 43: 503-6.
Wesołowska O, Krokoszyńska I, Krowarsch D, Otlewski J. (2001) Enhancement of chymotrypsin-inhibitor/substrate interactions by $3 \mathrm{M} \mathrm{NaCl}$. Biochim Biophys Acta.; 1545: $78-85$.

Wilimowska-Pelc A, Polanowski A, Kołaczkowska MK, Wieczorek M, Wilusz T. (1983a) Aspartyl proteinase from cucumber (Cucumis sativus) seeds. Preparation and characteristics. Acta Biochim Polon.; 30: $23-31$.

Wilimowska-Pelc A, Wieczorek M, Otlewski J, Leluk J, Wilusz T. (1983b) Immobilized Bowman-Birk inhibitor for selective isolation of chymotrypsin B from bovine pancreas. $J$ Chromatogr.; 269: 22-7.

Wilimowska-Pelc A, Stachowiak D, Gładysz M, Olichwier Z, Polanowski A. (1996)

Antiproteolytic activity of goose pancreas: purification, inhibitory properties and amino acid sequence of a Kazal type trypsin inhibitor. Acta Biochim Polon.; 43: 489-96.

Wilimowska-Pelc A, Olczak M, Olichwier Z, Gładysz M, Wilusz T. (1999a) Isolation and amino acid sequence of two trypsin isoinhibitors from duck pancreas. Comp Biochem Physiol.; 124B: 281-8.

Wilimowska-Pelc A, Olichwier Z, Kowalska J, Gałuszka A, Szuszkiewicz W, Polanowski A, Wilusz T. (1999b) High concentrations of sodium chloride facilitate the use of immobilized chymotrypsin for separating virgin forms of specific trypsin inhibitors. $J$ Chromatogr.; 852A: 227-35.

Wilusz T, Polanowski A. (1985)

Pepstatin-sensitive proteinase from Chlamydomonas reinhardtii. In Aspartic Proteinases and their Inhibitors. Kostka V. ed, pp 45-48. Walter de Gruyter \& Co, Berlin, New York.

Żelazko M. (2000) Isolation of proteolytic enzymes from goose pancreases with affinity chromatography on immobilized inhibitors. MSc Thesis, University of Wrocław, (in Polish). 